\title{
A Case Report of Congenital Non- spherocytic Hemolytic Anemia in a Patient from India
}

\author{
Ruhi Sonaye $^{1}$, Shaheen Sombans ${ }^{2}$, Kamleshun Ramphul ${ }^{3}$
}

1. Bharati Vidyapeeth Deemed University Medical College and Hospital, Thane, IND 2. Internal Medicine, Bharati Vidyapeeth University Medical College and Hospital, Pune, IND 3. Pediatrics, Shanghai Jiao Tong University School of Medicine/Shanghai Xin Hua Hospital, Shanghai, CHN

$\square$ Corresponding author: Shaheen Sombans, shaheensombans@gmail.com

Disclosures can be found in Additional Information at the end of the article

\section{Abstract}

Congenital non-spherocytic hemolytic anemia (CNSHA) is a rare autosomal recessive condition that presents as a congenital hemolytic anemia. The absence of vital enzymes required for glycolysis such as homozygous glucose phosphate isomerase (GPI) and red blood cell (RBC) nucleotide metabolism predisposes the RBCs to hemolysis. No spherocytosis is seen on peripheral smear as well as no signs of immune-mediated destruction of RBCs. We present a rare case of a previously healthy 21-year-old female patient with CNSHA from India.

Categories: Genetics, Internal Medicine, Rheumatology

Keywords: congenital non-spherocytic hemolytic anemia, india, pyruvate kinase deficiency, hexokinase deficiency, pyrimidine 5'nucleotidase deficiency, homozygous glucose phosphate isomerase deficiency

\section{Introduction}

Congenital non-spherocytic hemolytic anemia (CNSHA) is an autosomal recessive condition that leads to a deficiency of vital enzymes required for glycolysis and red blood cell (RBC) nucleotide metabolism. It presents as a congenital hemolytic anemia and patients also show signs of jaundice. No spherocytosis is observed on peripheral smear and laboratory findings also exclude hemoglobin abnormalities. We present a rare case of a patient with CNSHA.

\section{Case Presentation}

Received 04/11/2018

Review began 04/12/2018 Review ended 04/12/2018 Published 04/13/2018

(c) Copyright 2018

Sonaye et al. This is an open access article distributed under the terms of the Creative Commons Attribution License CC-BY 3.0., which permits unrestricted use, distribution, and reproduction in any medium, provided the original author and source are credited.
A previously healthy 21-year-old female patient born out of a non-consanguineous marriage presented at the emergency department of the Osmania General Hospital in India complaining vomiting and loose motion of unknown origin for five days. On physical examination, she had no other systemic abnormalities and she was admitted for further tests. During the stay, she gradually developed a petechial rash over both lower limbs and her platelet count was slightly lower than the normal range at 130,000 per microliter of blood. Vomiting and diarrhea subsided and she eventually developed a yellowish discoloration of the sclera and her urine turned dark yellow. Her total and direct bilirubin was $12.58 \mathrm{mg} / \mathrm{dL}$ and $9.8 \mathrm{mg} / \mathrm{dL}$, respectively. Physical examination at that point showed that her liver was palpable at $3 \mathrm{~cm}$ below the costal margin and splenomegaly was also noted.

Further laboratory testing showed that her percentage of RBCs was low (3.8 million cells/ul), mean corpuscular volume (MCV) and mean corpuscular hemoglobin (MCH) were normal at 98 
$\mathrm{fL} /$ red cell and 30 picograms/cell respectively, while her mean corpuscular hemoglobin concentration (MCHC) was slightly in the lower range at $32 \mathrm{~g} / \mathrm{dL}$. Peripheral blood smear showed no spherocytes. Microcytes were present and hypochromic cells were also found. Osmotic fragility test showed normal osmotic fragility, while she also tested negative for Glucose 6 phosphate dehydrogenase deficiency. Hemoglobin electrophoresis was normal and the patient had a negative direct Coomb's test and Sickling test. Ultrasound of the abdomen confirmed hepatosplenomegaly. A pedigree diagram was made (Figure 1) and it showed that her mother and maternal aunt had similar symptoms but were never diagnosed for the condition. Due to the lack of appropriate laboratory facilities, the enzyme levels were not tested and the physicians relied more on the clinical presentation, physical examination and other laboratory results to make a clinical diagnosis of congenital non-spherocytic hemolytic anemia. She was treated for anemia (hemoglobin level of $6.7 \mathrm{~g} / \mathrm{dL}$ ) with blood transfusions and additional symptomatic care such as proper hydration was initiated. The patient gradually improved over a week and was discharged.

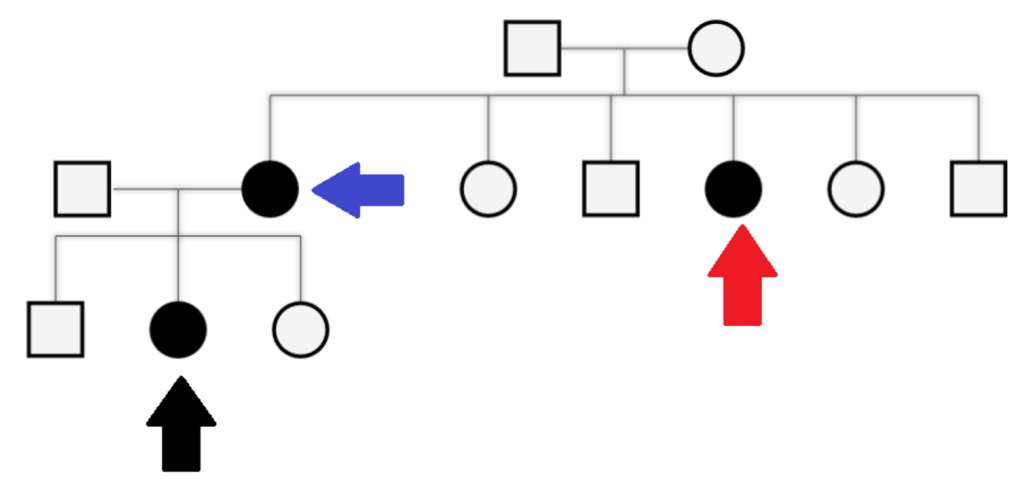

FIGURE 1: Pedigree diagram with the black arrow representing the patient, the blue arrow the patient's mother and the red arrow the patient's maternal aunt. All three of them had a history of similar symptoms.

\section{Discussion}

Congenital non-spherocytic hemolytic anemia is a rare condition with an autosomal recessive pattern. It is due to altered RBC metabolisms and shows the absence of any spherocytes or inclusion bodies on peripheral smear [1]. Clinical symptoms include pallor and fatigue from anemia as well as dark yellow urine and jaundice from hyperbilirubinemia. Patients are usually negative for any autohemolytic tests such as Coombs test. Our patient was a previously healthy female, with an apparent family history of similar complaints from her mother and maternal aunt. Her peripheral smear also was compliant with the diagnosis of CNSHA. Patients with CNSHA tend to have a normal hemoglobin structure and stability. Different enzymes deficiencies have been reported such as pyruvate kinase deficiency, hexokinase deficiency [2], pyrimidine 5'nucleotidase deficiency [3] and homozygous glucose phosphate isomerase (GPI) deficiency [4] causing a decrease in adenosine triphosphate (ATP) levels which eventually leads 
to RBC death and hemolysis [5-6]. Warang et al. used a molecular modeling to show that mutations of L487F can cause a loss of the ability of GPI to dimerize, causing the RBCs to have lower thermostability and significant changes in metabolisms leading to hemolysis [7].

Treatment of the condition involves symptomatic care and the patient should be advised to avoid any factors that can precipitate the hemolysis such as any drugs, stress or food [8]. Recovery of our patient was uneventful following the proper management of her anemia and symptoms. She was also advised to seek genetic testing and counseling before any planned pregnancies.

\section{Conclusions}

Congenital non-spherocytic hemolytic anemia is a rare autosomal recessive condition causing enzyme deficiencies that lead to congenital hemolytic anemia and usually no spherocytosis and hemoglobin abnormalities are present. Clinical symptoms usually include jaundice from high levels of bilirubin and pallor and fatigue from anemia. Treatment consists of symptomatic management and proper advice on genetic counseling.

\section{Additional Information \\ Disclosures}

Human subjects: Consent was obtained by all participants in this study. Conflicts of interest: In compliance with the ICMJE uniform disclosure form, all authors declare the following:

Payment/services info: All authors have declared that no financial support was received from any organization for the submitted work. Financial relationships: All authors have declared that they have no financial relationships at present or within the previous three years with any organizations that might have an interest in the submitted work. Other relationships: All authors have declared that there are no other relationships or activities that could appear to have influenced the submitted work.

\section{References}

1. Zipursky A, Rowland M, Peters JC, Israels LG: Congenital non-spherocytic hemolytic anemia. Can Med Assoc J. 1965, 93:1141-1146.

2. de Vooght KM, van Solinge WW, van Wesel AC, Kersting S, van Wijk R: First mutation in the red blood cell-specific promoter of hexokinase combined with a novel missense mutation causes hexokinase deficiency and mild chronic hemolysis. Haematologica. 2009, 94:12031210. 10.3324/haematol.2008.002881

3. Fujii H, Miwa S: Recent progress in the molecular genetic analysis of erythroenzymopathy . Am J Hematol. 1990, 34:301-310. 10.1002/ajh.2830340412

4. Manco L, Bento C2, Victor BL, et al.: Hereditary nonspherocytic hemolytic anemia caused by red cell glucose-6-phosphate isomerase (GPI) deficiency in two Portuguese patients: clinical features and molecular study. Blood Cells Mol Dis. 2016, 60:18-23.

10.1016/j.bcmd.2016.06.002

5. Beutler E, Baranko PV, Feagler J, Matsumoto F, Miro-Quesdada M, Selby G, Singh P: Hemolytic anemia due to pyrimidine-5'-nucleotidase deficiency: report of eight cases in six families. Blood. 1980, 56:251-255.

6. Miwa S, Nakashima K, Fujii H, Matsumoto M, Nomura K: Three cases of hereditary hemolytic anemia with pyrimidine 5'-nucleotidase deficiency in a Japanese family. Human Genet. 1977, 37:361-364. 10.1007/BF00393621

7. Warang P, Kedar P, Ghosh K, Colah RB: Hereditary non-spherocytic hemolytic anemia and severe glucose phosphate isomerase deficiency in an Indian patient homozygous for the L487F mutation in the human GPI gene. Int J Hematol. 2012, 96:263-267. 10.1007/s12185012-1122-x

8. Anemia, hereditary nonspherocytic hemolytic . (2007). Accessed: Apri 10, 2018: 


\section{Cureus}

http://rarediseases.org/rare-diseases/anemia-hereditary-nonspherocytic-hemolytic. 